\title{
Paroxysmal Headache as First Finding of Pheochromocytoma: A Case Report
}

\section{Feokromasitomanın İlk Bulgusu Olarak Paroksismal Baş Ağrısı: Olgu Sunumu}

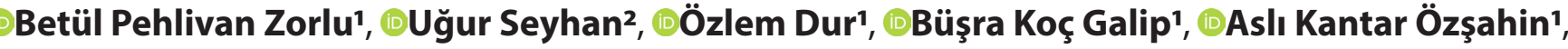 \\ ๑Mehmet Coşkun ${ }^{3}$, -Fatma Devrim'1, @Nida Temizkan Dinçel' \\ 'University of Health Sciences, Dr. Behcet Uz Children Hospital, Department of Pediatric Nephrology, Izmir, Turkey \\ 2Sancaktepe Şehit Prof ·Dr. İlhan Varank Training and Research Hospital, Istanbul, Turkey \\ 3University of Health Sciences, Dr. Behcet Uz Children Hospital, Department of Radiology, Izmir, Turkey
}

\begin{abstract}
Pheochromocytoma is a rare tumor that develops from the chromaffin cells of the sympathetic nervous system. Although hypertension is the most common manifestation of pheochromocytoma, it is less common in children than in adults. This condition may be overlooked like in our patient who had an undiagnosed headache for several years. Our patient was admitted to our emergency department due to the increase in headache, which lasted for about 6 years, and a neurological evaluation was performed. Due to the high blood pressure in her follow-up, she was examined further. Abdominal USG revealed a $36 \times 26 \times 27 \mathrm{~mm}$ solid lesion in the right adrenal gland with a mild hyperechogenic appearance with a cystic component. With supporting findings in magnetic resonance imaging and high catecholamine levels in blood, she was diagnosed with pheochromocytoma. Our aim in sharing this case is to emphasize the importance of measuring blood pressure in patients accurately and at each examination, evaluating them with percentile charts, and monitoring them closely.
\end{abstract}

Keywords: Pheochromocytoma, children, headache, hypertension

\section{INTRODUCTION}

Pheochromocytoma is a tumor that develops from chromaffin cells of the sympathetic nervous system. ${ }^{[1]}$ Pheochromocytomas originate from the adrenal medulla, paragangliomas originate from extra-adrenal cells. It is mostly located in the head and neck but it can be found in the thorax, abdomen, pelvis and bladder. ${ }^{[2]}$ Although hypertension is the most common manifestation of pheochromocytoma, it is less common in children than in adults. ${ }^{[3]}$ Palpitations, headache,

\section{Öz}

Feokromasitoma sempatik sinir sisteminin kromaffin hücrelerinden gelişen nadir görülen bir tümördür. Hipertansiyon feokromasitomanın en sık bulgusu olmasına rağmen, bu durum çocuklarda erişkinlere göre daha az sıkıkta görülmektedir. Uzun zamandır tanı konulamayan baş ağrısı şikayeti ile başvuran hastamızda gözden kaçırılabilecek bu kliniği değerlendirdik. Hastamız yaklaşık 6 yıldır süren baş ağrısı şikayetinin artması nedeni ile acil servisimize başvurmuş, takibinde nörolojik değerlendirme yapıımıştır. İleminde kan basıncı yüksekliği saptanması üzerine ileri tetkik edilmiş ve abdominal ultrasonografide sağ sürrenal bezde 36×26×27 mm boyutlarında içerisinde kistik bileşeni bulunan hafif hiperekojen görünümde solid lezyon saptanması, kitlenin manyetik rezonans görüntüleme ve katekolamin yüksekliği ile desteklenmesi ile feokromasitoma tanısı konulmuştur. Olguyu paylaşmamızdaki amacımız hastalarda kan basıncı ölçümünün doğru şekilde ve her muayenede yapılması, persentil çizelgeleri ile değerlendirilmesi ve yakın takibinin önemini vurgulamaktır.

Anahtar Kelimeler: Feokromasitoma, çocuk, baş ağrııı, hipertansiyon

excessive sweating, and pallor are the main symptoms that may cue pheochromocytoma, but the classic symptoms in children are less common and are characteristically more persistent than paroxysmal as in adults. Sweating, nausea, vomiting, weight loss, polyuria, anxiety, and visual disturbances have been reported more frequently in children than in adults. ${ }^{[5,}{ }^{6]}$ Although the percentage of hereditary cases is not clearly known, there is a high and heterogeneous genetic predisposition. However, pheochromocytomas may

Corresponding (IIletişim): Betül Pehlivan Zorlu, University of Health Sciences, Dr. Behcet Uz Children Hospital, Department of Pediatric Nephrology, Izmir, Turkey

E-mail (E-posta): betulpehlivantr@gmail.com

Received (Geliş Tarihi): 13.12.20 Accepted (Kabul Tarihi): 22.12 .20 
be associated with Von Hippel-Lindau (VHL) disease, familial paraganglioma, and multiple endocrine neoplasia type $2 \mathrm{~A}^{\left[{ }^{[4]}\right.}$

Hereditary, bilateral, extra-adrenal, and multifocal pheochromocytomas are more common in children than adults. ${ }^{[5]}$ This condition is rare and may be overlooked. In this paper, we present a case who was admitted with a headache that could not be diagnosed for several years.

\section{CASE}

A previously healthy 16 years old girl was admitted to our emergency department due to her headache which has occured often for 6 years, lasts 6-7 hours and does not respond to painkillers, worsened in the last 2 weeks. Our patient did not describe photophobia- phonophobia or nause and vomiting. Palpitations and flushing were also not accompanied. There was a 1st degree cousin marriage between mother and father, an abortion history of the mother in her family history. There was no history of migraine in the family.

On physical examination; height: $164 \mathrm{~cm}$ (SD: 0.26), weight $61 \mathrm{~kg}$ (SD: 0.79), heart rate: 152/min, blood pressure: 140/110 $\mathrm{mmHg}$, respiration rate: 24 , body temperature: $36.6^{\circ} \mathrm{C}$. Other physical examination findings were normal. In laboratory examination; hemoglobin:12.1 g/dL (RR: 11.7-15.3), white blood cells:10280/microL (RR: 4.1-11.0), platelets: 582000/ microL (RR: 150000-450000), kidney, liver and thyroid function tests, urine analysis were normal; there was no ion imbalance. CRP was negative, no acidosis, lactate was normal. The patient consulted to pediatric neurology. Neurological examination was normal, vitamin B12 level was 240 pg/nl (RR: 200-900), there were moderate atrophic changes in contrast-enhanced cranial MR. Due to high blood pressure levels during the follow-up, the patient consulted to pediatric nephrology.

There was no previous urinary tract infection, use of herbal medicine used for energy or weight loss in the patient's history. There were no risk factors such as obesity or sleep apnea. It was learned that her father, uncle and aunt had kidney stones and also her aunt had a history of nephrectomy. There was no known high blood pressure value in previous admissions. The patient was hospitalized and evaluated. Complete blood count, renal function tests and urine analysis were found to be normal. Upon the persistence of high blood pressure, the etiology of hypertension was examined, amlodipine and enalapril treatments used for treatment. Abdominal ultrasonography revealed a $36 \times 26 \times 27 \mathrm{~mm}$ solid lesion in the right adrenal gland with a mild hyperechogenic appearance with 2 cystic components, approximately $7 \mathrm{~mm}$ in diameter. In contrast-enhanced abdominal magnetic resonance imaging (MRI); liver long axis was measured $166 \mathrm{~mm}$, hepatomegaly was present, both kidneys were normal in size, parenchyma and echogenicity. In the right adrenal gland, a solid lesion, $30 \times 27 \mathrm{~mm}$ in size, with circumscribed and round appearance was observed. It had low signal in T1 weighed imaging (WI), high signal in $\mathrm{T} 2 \mathrm{Wl}$, and no contrast enhancement. Postcontrast imaging was standard T1WI fast spin echo. Since there was no dynamic- fast imaging, it was thought that the lesion had washed out from contrast in standard T1WI. Due to the high T2 signal, the pre-diagnosis was pheochromocytoma (Figure 1). The patient examined for end organ damage due to hypertension, there was no microalbuminuria, fundus was normal, cardiological examination was normal. Metanephrine and normetanephrine levels were found to be high in urine, and blood levels of vanillylmandelic acid acid were found to be high, and 5-hydroxyindoleacetic acid and homovanillic acid were within normal limits (Table 1).

\begin{tabular}{|c|c|c|c|}
\hline & Pre-op & $\begin{array}{l}\text { Post-op 6th } \\
\text { month }\end{array}$ & $\begin{array}{l}\text { Reference } \\
\text { Range }\end{array}$ \\
\hline Metanephrine $(\mu \mathrm{g} / 24 \mathrm{~h})$ & 93 & 122.9 & $(52-341)$ \\
\hline Normetanephrine ( $\mu \mathrm{g} / 24 \mathrm{~h})$ & 101224 & 152,9 & $(88-444)$ \\
\hline Urine 24-hour volume & & 2100 & \\
\hline $\begin{array}{l}\text { Vanillylmandelic acid } \\
\text { (mg/24h) }\end{array}$ & 12 & & $(1,6-7,3)$ \\
\hline $\begin{array}{l}\text { Homovanillic acid } \\
\text { (Urine 24-hour) (mg/24h) }\end{array}$ & 3 & & $(1,82-6,92)$ \\
\hline $\begin{array}{l}\text { 5-Hydroxyindoleacetic acid } \\
\text { (Urine 24-hour) (mg/24h) }\end{array}$ & 5 & & $(2-8)$ \\
\hline
\end{tabular}

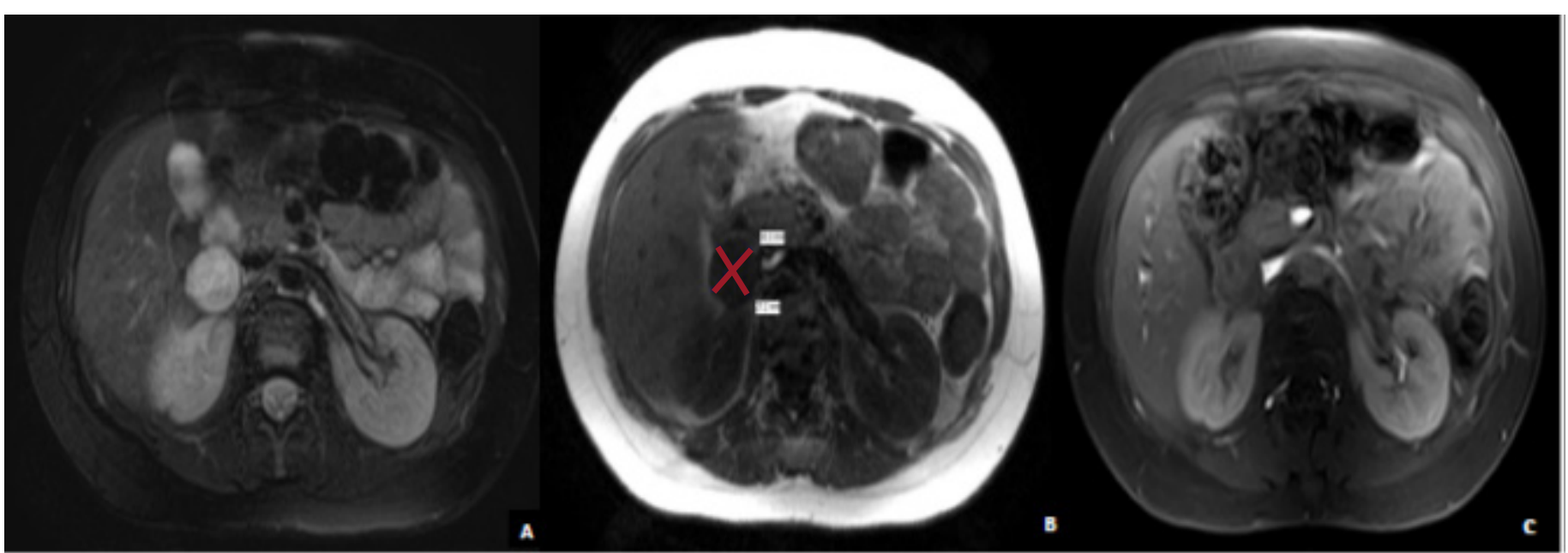

Figure 1. A: T2 weighed imaging B:T1 weighed imaging C: Contrast in T1 weighed imaging 
The antihypertensives that the patient was taking were stopped and doxazosin treatment was started. In order to exclude multiple endocrine neoplastic syndromes, blood tests were performed; IGF-1: 162 ng/ml (RR: 153-611), IGFBP-3: $5.03 \mu \mathrm{g} / \mathrm{ml}$ (RR: 3.4-9.5) ve calcitonin: $<2 \mathrm{pg} / \mathrm{ml}(\mathrm{RR}: \leq 5.0)$. Pituitary MRI and thyroid ultrasonography were normal. VHL gene analysis has been done. NSE:14,98 $\mu \mathrm{g} / \mathrm{L}(\mathrm{RR}: \leq 15.0)$, AFP: $<2,72 \mu \mathrm{g} / \mathrm{L}(\mathrm{RR}:<8.4)$ CA15-3: 5,05 U/mL (RR: <30) were found to be normal. Positron emission tomography performed for surgical evaluation, revealed a mass lesion with increased somatostatin receptor expression in the right side of the vena cava inferior, posterior to the duodenum, anterior adjacent to the kidney, caudal to the right surrenal gland, between the adrenal gland corpus and the lateral crus. There was no zone with increased Ga-68 DOTATATE uptake that might indicate a metastasis.

During the surgical preparation process, her blood pressure progressed to stage 2 hypertension and an alpha-beta blocker was started. It regressed to pre-hypertensive values in the follow-up. Adrenal-sparing surgery was performed. In the postoperative follow up; a hypertensive value was found only once, her headache did not persist, she had no additional problems, therefore she was discharged. Metanephrine and normetanephrine values were found to be normal in the urine examined 6 months later. (Table 1) Pathological examination revealed a well-circumscribed tumor with a diameter of 3.5 $\mathrm{cm}$ in pheochromocytoma morphology with a prominent Zell Ballen pattern in the right adrenalectomy material. There were no findings suggesting malignancy.

\section{DISCUSSION}

Pheochromocytoma in children is rare, accounting for $5 \%$ of all diagnoses. Approximately $80 \%$ of the cases originate from the adrenal medulla. ${ }^{[5]}$ Most cases are sporadic, but around 40$60 \%$ can be part of hereditary syndromes. Hypertensive crisis in pheochromocytoma is an endocrine emergency associated with severe mortality. This is a catecholamine-induced acute severe hemodynamic disorder that causes end organ damage or dysfunction. ${ }^{[7]}$ The most common complaints are headache and hypertension. Although our patient has had a headache for about 6 years, no high blood pressure was detected in her admissions. According to the study of Babic et al., the percentage of admission with headache was $2 \%$ and with hypertension was $17 \%$. Our patient had a complaint of constant headache. Persistent hypertension is present in $60-90 \%$ of children. However, there is no requirement of hypertension for a diagnosis, and there is no clear relationship between catecholamine levels and the symptoms. While the mean age at diagnosis was 13.9 years in the study of Babic et al.,and 11 years in the study of Havakes et al., the age at diagnosis of our case was $16 .^{[5,8]}$

Family history is encountered at a percentage of $10 \%$, and family history is not present in our case. ${ }^{[4,9]}$ Among the hereditary syndromes, multiple endocrine neoplasia type 2, von Hippel Lindau syndrome, neurofibromatosis type 1 and familial paraganglioma syndromes are most frequently observed in relation with pheochromocytoma. Genetic defect in intracellular oxygen balance in Von Hippel Lindau Syndrome can lead to intense excessive cell proliferation in blood vessels. It mostly occurs as angioma in retina of the eye, hemangioblastoma in brain or spinal cord, endolymphatic sac tumor in inner ear, kidney cell carcinoma, pheochromocytoma in adrenal gland, serous cystadenoma in pancreas, or papillary cystadenoma in epididymis or uterine ligament. The occurrence of the disease can vary significantly and patients may show symptoms at any time from early childhood to adulthood. Phenotypically the disease is divided into 4 types; VHL type 1 is predominantly without pheochromocytoma, and VHL type 2 is predominantly with pheochromocytoma. Type 2 is subdivided to type $2 \mathrm{~A}$ (with renal cancer) and type $2 \mathrm{~B}$ is (without renal cancer). In type $2 \mathrm{C}$, there are solely pheochromocytomas. Therefore, the VHL gene mutation we examined in our patient resulted as negative. It should be noted that, together with the increased knowledge and expanding genetic test analysis, patients with negative genetic screening may have germline mutation in the future. Genetic screening is very important because it indicates an increased risk of recurrence and malignancy. ${ }^{[10]}$

It is known that malignant pheochromocytoma cases are less common in children. $10-15 \%$ of pheochromocytomas and 20$50 \%$ of paragangliomas may be malignant. ${ }^{[10]}$ In our patient, no malignancy was detected as a result of the pathological examination. Biochemical markers are very important in diagnosis, they include examination of catecholamine levels and urinary vanillylmandelic acid in 24-hour urine and plasma. Metanephrine and normetanephrine levels in blood are $100 \%$ sensitive and $94 \%$ specific in children, and the level of normetanephrine was found to be significantly higher in our patient at diagnosis. Although magnetic resonance imaging is $90-100 \%$ sensitive in diagnosis, it may be insufficient to distinguish pheochromocytoma from other abdominal lesions. Therefore, as in our patient, 123 metaiodobenzylguanidine (MIBG) scintigraphy should be added to the examinations to confirm the diagnosis, to catch clues about malignancy, and to detect other foci, if any. ${ }^{[5]}$

In our case, the patient was diagnosed with pheochromocytoma with detection of a solitary lesion in abdominal ultrasonography after normal results of urinary ultrasonography performed for hypertension, abdominal MRI and high levels of metanephrine and normetanephrine in the urine.Thegold standard in diagnosis is the elevation of catecholamine and its metabolites in urine, which was also present in our patient. In pheochromocytoma crisis, treatment management includes the use of alphablockers and surgical intervention should be delayed until medical stabilization is established..$^{[7,}{ }^{8]}$ Alpha-blocker was used in our patient during the surgical preparation process. In the study of Havekes et al., it was stated that calcium channel blockers alone are not sufficient to control blood pressure or may be useful when side effects are seen. ${ }^{[5]}$ Our patient, who did not have metastatic lesions on scintigraphy, was hospitalized approximately 2 weeks before the planned operation date and was operated after blood pressure regulation was achieved. 


\section{CONCLUSION}

Finally, as pheochromocytoma can be accompanied with many findings and symptoms, it should also be considered with the differential diagnosis of headache. Hypertension may be absent, or it can be seen paroxysmally as in adults. It is very important to measure blood pressure in patients accurately and at each examination, evaluate them with percentile charts, and monitor them closely. It is necessary to be suspicious in certain situations and the pheochromocytoma should be brought to mind. In this disease, in which family history is significant, family screening or follow-up is also important in terms of cases that are missed or have not yet shown any symptoms.

\section{ETHICAL CONSIDERATIONS}

Informed Consent: Written informed consent was obtained from all participants who participated in this study.

Status of Peer-review: Externally peer-reviewed.

Conflict of Interest Statement: The authors have no conflicts of interest to declare.

Financial Disclosure: The authors declared that this study has received no financial support.

Author Contributions: All of the authors declare that they have all participated in the design, execution, and analysis of the paper, and that they have approved the final version.

\section{REFERENCES}

1. Coutant R, Pein F, Adamsbaum $C$, et al. Prognosis of children with malignant pheochromocytoma. Report of 2 cases and review of the literature. Horm Res. 1999;52(3):145-9.

2. Flynn, I.Y.a.J.T., Pathophysiology of Pediatric Hypertension, in Pediatric Nephrology, E.D. Avner, Editor. 2016.

3. Fonseca V, Bouloux PM. Phaeochromocytoma and paraganglioma. Baillieres Clin Endocrinol Metab 1993;7(2):509-44.

4. Igaki J, Nishi A, Sato T, Hasegawa T. A pediatric case of pheochromocytoma without apparent hypertension associated with von Hippel-Lindau disease. Clin Pediatr Endocrinol. 2018;27(2):87-93.

5. Havekes B, Romijn JA, Eisenhofer G, Adams K, Pacak K. Update on pediatric pheochromocytoma. Pediatr Nephrol. 2009;24(5):943-50.

6. Kohane DS, Ingelfinger JR, Nimkin K, Wu CL. Case records of the Massachusetts General Hospital. Case 16-2005. A nine-year-old girl with headaches and hypertension. N Engl J Med. 2005;352(21):2223-31.

7. Pekic $S$, Jovanovic $V$, Tasic $G$, et al. Intracerebral hemorrhage as a first sign of pheochromocytoma: case report and review of the literature. Endokrynol Pol. 2019;70(3):298-303.

8. Babic B, Patel D, Aufforth R, et al. Pediatric patients with pheochromocytoma and paraganglioma should have routine preoperative genetic testing for common susceptibility genes in addition to imaging to detect extraadrenal and metastatic tumors. Surgery. 2017;161(1):220-7.

9. Prabhu M, Joseph TT, Shetty N, Chaudhuri S. Child with bilateral pheochromocytoma and a surgically solitary kidney: Anesthetic challenges. Saudi J Anaesth. 2013;7(2):197-9.

10. Pappachan JM, Tun NN, Arunagirinathan G, Sodi R, Hanna FWF. Pheochromocytomas and Hypertension. Curr Hypertens Rep. 2018;20(1):3. 